\title{
EURÓPA - VILÁGI ÉS VALLÁSI ÉRDEKEINK ÉS ESZMÉNYEINK TERE
}

\author{
HIDAS ZOLTÁN
}

\begin{abstract}
Europe - The Field of our Worldly and Religious Interests and Ideals

The present study aims at delivering some crucial aspects of thinking about Europe, this subcontinent with vague geographical profiles. The starting point of my considerations is a deep contemporary sense of crisis concerning the future of our inherited world, faced with other cultural and material elements carried by migration processes. Firstly, based on Max Weber's distinction between worldly and religious, the specific modern European culture is outlined in its differentiation of several spheres of interests and ideas (such as economy, politics, science, religion). The ideal-typical reconstruction of the modern European relation to the world, called world-dominance, reveals not only a specifically active and forming attitude but also clear signs of the presence of religion. In a second step, the main cultural and material roots of Europe are developed in their heterogenities, conflicts and combinations. Ancient Greek and Biblical traditions are prolonged, renewed and partly replaced by Enlightenment projects of freedom and sovereignty. Europe seems to be a historically singular stress-field of material and ideal factors. The self-exploring freedom, the creative productivity and the self-critical criticism of man, bound up with respectful reciprocity in the order of interdependence: these fundaments of recent European humanity cannot be harmonized with any other vision of the world.
\end{abstract}

\section{BEVEZETÉS}

A jelenünkben való sokféle eligazodási törekvés talán egyetlen közös szava szerint Európa „válságban” van. ${ }^{1}$ A krízis orvoslásból átkölcsönzött kategóriája már antik görög gyökereinél is választási helyzetet jelöl: itt és most válik, azaz dől el a jövő.

${ }^{1}$ Az Európa-kérdés történészi áttekintéséhez lásd Gyurgyák János: Európa alkonya? Utak és tévutak az európai történelemben és politikában. Budapest, Osiris, 2018. 
Amikor a tét az életben maradás, meghatározó ógörög felfogás szerint a megoldás a jó rend ritmusához való visszatérés. Gondolkodásunk egy jellegzetesnek számító újkori sajátossága szerint azonban várakozásaink elszakadtak a tapasztalatainktól. Ha állandóan mozgásban lévőnek észlelt világunk nem azonos sémák ismétlődését hozza, hanem folyamatosan új helyzeteket teremt, akkor minden pillanat döntéseket hordoz. Ez a szemlélet időnként permanens válságtudatot is gerjeszt, mindenesetre a mindenkori helyzetet bizonytalan végkimenetelü mozgások pillanatnyi összefüggéseként látja. Kiélezettnek látott mai helyzetünkben az egyik elvi végponton a múlt megtartó elemeinek elvesztésétől való félelem apokaliptikus látványokat kelt: innen nézve az igazi szabadság a meglévő keretek betöltése. A másik végponton a múlt visszatartó elemeibe való beleragadás rettenete eszkatológiákat szül: innen nézve a tágabb kötetlenségbe való haladó előrelépés jelenti a szabadságba való igazi belépést. ${ }^{2}$

Az ezer éve alakuló szubkontinentális valóság középkori neveit - a „latin nyugatot” és a „katolikus kereszténységet” - kétszáz éve a felvilágosító törekvés váltotta le a Hérodotosztól vett Európára. Jelenkori világunk önmeghatározási nehézsége ennek a névadásnak a - minden mitikus vonatkozás ellenére - formális voltában is megjelenik: a „nyugat” (föníciai erob) semmitmondása az „újkor” rokona. Az európai Nyugaton kialakult újabb viszonyok értése így számunkra, „európaiak” számára magának az újkornak az eredeztetési problémáival is belsőleg összefügg.

Hegel szerint a filozófia nem más, mint a „kor - gondolatokba foglaltan”. $\mathrm{Az}$ érvényes világmegragadás eszközei a valóságos totalitással, azaz a Világtörténelemmel végső soron egybeeső totalitásfogalmak, amilyen a "Világszellem”, valamint a belőlük levezetett részfogalmak, amilyen a „népszellem”. Ujkori mozgásaink végre a beteljesülés közelébe vittek bennünket: az elsőként Jézus által istenemberként megtestesített és mindenki számára meghirdetett teljes szabadság, véges és végtelen szintézise az európai újkorban, a reformáció és a forradalmak által jutott a történelmi megvalósulás közegébe. A belső szabadságnak, vagyis Hegel szerint az általánosságnak azonban a külső világban kellően „tagoltnak” kell lennie: az egyén és a legmagasabb intézmények - kétszáz évvel ezelött éppenséggel a porosz állam - között közvetítő rendek és intézmények teremtik meg a szükséges kapcsolatot. A szabadság által szült világi rend túl van a szerződéses viszonyok önkényességén, de innen van a „minden mindenben” (1Kor 15,28) világvégi teljességén. A szellemet egykor hordozó kultúrák kiüresedett burokként maradtak vissza a világtör-

\footnotetext{
${ }^{2}$ E két gondolkodási stílushoz lásd főként Mannheim Károly tudásszociológiáját: Tudásszociológiai tanulmányok. Budapest, Osiris, 2000.

${ }^{3}$ Georg Wilhelm Friedrich Hegel: Grundlinien der Philosophie des Rechts. Werke 7, Frankfurt a. M., Suhrkamp, 1970, 26.
} 
ténelem bontakozási folyamatában: a legjobban teszik, ha felhágnak a mások által elért magaslatokra. ${ }^{4}$

Max Weber hasonló fesztávú - a világtörténés emberi felmérhetetlensége miatt egyáltalán lehetségesnek tartott - programja a jelen szövevényes összefüggéseinek megértési kísérlete a keletkezésekből, más szóval a történések saját szempontjainkhoz igazodó gondolati rendezése. ${ }^{5}$ A múlt és a jelen egyidejü rekonstrukciós kísérleteiben szempontok, azaz megközelítések feszülnek egymásnak: aki a kultúrákat tisztán materiális erőviszonyok centrális és periférikus viszonyaiból magyarázza, ${ }^{6}$ az eszmék hatását minden kimutatásában másodrendűnek fogja tartani. Aki Európában a túlélésért vívott evolúciós harcosok egy sajátos példányát látja, az elismerheti az eszmények, azaz hiedelmek mint hasznos társas konstrukciók erejét, az eredendőségük és hatóerejük elismerése nélkül.

A jövő mindkét említett látomása a múltra irányul, miközben mindkettőnek számot kell vetnie a jelen belső és külső erőivel. Mindezek alapján mindenekelőtt a történéseket meghatározó erőtényezőkről kell elvi döntést hoznia annak, aki a múlt sokféleségében is gyökerező és az akart jövőhöz is viszonyuló jelen egyszeri konstellációjában és annak feszültségviszonyaiban eligazodást keres. A jelenkor megragadási nehézségei nem változnak attól sem, ha képletekbe számszerüsítjük az alakulásokat.?

\section{AZ ÚJKORI EURÓPAISÁG VILÁGVISZONYA}

Weber egy elvi igényű megfogalmazása szerint mindenekelőtt érdekek mozgatják az emberi cselekvést, de a világképekké szerveződő eszmék azok, amelyek - mint valami vasúti váltók - az érdekek pályáit kijelölik. Az eszmék közege az anyagi és szellemi érdekek és a fennállóvá intézményesült rendek világa. ${ }^{8}$ Igy tekintve Eu-

${ }^{4}$ Lásd Georg Wilhelm Friedrich Hegel: Előadások a világtörténet filozófiájáról. Budapest, Akadémiai, 1966.

${ }^{5}$ Max Weber: „A társadalomtudományos és társadalompolitikai megismerés »objektivitása«." In uő: Tanulmányok. Budapest, Osiris, 1998, 7-69, főként 29 skk.

${ }^{6}$ Immanuel Wallerstein: Bevezetés a világrendszer-elméletbe. Budapest, L'Harmattan, 2010.

${ }^{7}$ Tanulmányunk nem tárgyalja Európát mint hullámszerűen megjelenő látomások és tervek történetét (lásd pl. Németh István [szerk.]: Európa-tervek. 1300-1945. Budapest, Eötvös, 2001), amelyeknek persze nyilvánvaló a hatása Európa „valóságára”.

${ }^{8}$ Max Weber: „Bevezetés”. In uő: Világvallások gazdasági etikája. Vallásszociológiai tanulmányok. Válogatás. Budapest, Gondolat, 2007, 65 skk.; vö. Wolfgang Schluchter: „Interessen, Ideen, Institutionen: Schlüsselbegriffe einer an Max Weber orientierter Soziologie." In uő: Die Entzauberung der Welt. Sechs Studien zu Max Weber. Tübingen, Mohr Siebeck, 2009, 18-39. A kultúrának ehhez a fogalmához lásd Hidas Zoltán: Törékeny értelemvilágaink. A világalakitás rendje és szabadsága. Budapest, Gondolat, 2018, 11-41. 
rópa jellegét és lendületét századokon át a világszervezés itt kibontakozott sajátos módja adta, a világhoz és önmagunkhoz való viszonyunk szerint.

Ami a közelmúlt legmeghatározóbbnak tartott változásait illeti: az újkori kapitalizmus születési helye, minden viszonylagos lemaradása ellenére, továbbra is a gazdasági világ egyik erőközéppontja. A gazdasági hatékonyság azonban egyre többek bevonását követeli meg emberi erőforrásként, lehetőleg egyre alacsonyabb ráfordítással. Az európainak nevezett világ legelemibb újratermelési folyamataiban ténynek számít, hogy népessége elöregszik. A hosszú harcokban kialkudott jóléti rend békéje még a lassú, de állandó gyarapodás lehetőségével kötötte meg a munkát. A piac elve azonban egyre következetesebben követeli meg a magáét: mindinkább a kellően „rugalmas” tevékenységhez rendelt jutalmakkal teremt versengést. A Föld lélekszámának roppant növekedése és a megélhetési lehetőségek súlyos aránytalanságai közepette mégis sokak számára válik vonzó életlehetőséggé az „öreg”, de összességében rendkívüli életszínvonalú kontinens. Az egyes országok által föleg kisegítő munkára hívott távoli népességcsoportok megjelenéséhez már hosszabb ideje olyan mozgások társulnak, amelyek a „tömeges migráció” vagy akár - a jelenség elővételezett távlatai miatt - a „népvándorlás” nevet kapják. De vajon a termelékenység, az életkormutató vagy a népességarány milyen összefüggésben van a világ szellemi megteremtésével, vagy éppen a munka az emberrel mint egy adott kultúra eleven hordozójával?

Eközben a hagyományos határokon túllépő kapcsolódások „Európai Unió” néven az európai rend új körvonalait látszanak megteremteni: a belső mozgások évtizedek óta egyre könnyebbé váltak, a legtágabb értelemben vett erők és javak áramlása előtti akadályok elhárultak. Ennek az egységesülésnek a legújabb intézményes formája a régi politikai birodalom helyett az érdekazonosságban fogant gazdasági társulás, amelynek - „Európára” hivatkozva - mindinkább értékközösségi igényei is vannak. A gazdasági viszonyok átfogó rendje fokozatosan kiterjed a legkülönfélébb területek egyközéppontú megszervezésére: az egységen belüli telephelyek így már nem országok szerint oszlanak meg. Mindez persze nem oltja ki, legfeljebb új alakba önti a legmélyebb érdekellentéteket, amelyek legalább időleges kezelésére az európai újkorban jött létre a birodalmakat és államokat is kordában tartani képes „népjogi” rendszer. A régi különbségeket a belső mozgás történelmileg páratlan lehetősége legalább annyira felülírja, mint amennyire megerősíti és kiterjeszti. Ha most az akaratérvényesítési küzdelmeket tekintjük, az érdekek legfőbb hordozói az államok és a nevükben fellépő kormányzatok, amelyekhez új szereplőként járul maga a szervezett egység. A középpontban vívott elosztási küzdelmeknek, amelyek a legkevésbé sem egyforma hatalmú szereplők között zajlanak, a jól ismert eszköze az elosztásról szóló beszédpolitikai harc, amely szívesen folyamodik statisztikai fegyverekhez is. Mindezeket a legkülönfélébb kiegyenlítési mechanizmusok igyekeznek mederben tartani, amelyek eredménye a fennálló erőviszonyok 
formalizált folytonossága. Európa mint politikai tér azonban egyelöre híján van a legalapvetőbb kérdésekről szóló viták általánosan elfogadott színhelyeinek és eljárásainak. De vajon ilyen körülmények között mekkora az intézményes szervezettség egyéni cselekvésalakító hatóköre?

Ehhez a feszültségekkel teli politikai egységhez megújuló erőfeszítések igyekeznek utólagos kötődést is teremteni: a fennmaradáshoz külső alkotmányon kívül belső tartalmakat kapcsolni. A rendszeresen felmerülő igény szerint az átfogó rend tartós elfogadottsága egy egységesnek tekintett kulturális tér meglétén alapszik. Sokak szerint európai-nyugati világszemléletünk mozgása az egységesülés felé tart: a „modernizálódásnak” nevezett változásfolyamatok szellemi jegye az egyre egyetemesebb értékek melletti elköteleződés, a mindenkiben ott lakozó általános észtől a sajátos empirizmuson nyugvó tudományosságon át az egyetemes emberi jogokig. Legfőbb kulturális alapzatként az alapértéknek mondott szabadság fogalma szolgál, mindenekelőtt a szellemi „kiskorúságból”9 (Kant) kilépett ember személyes önrendelkezése értelmében. Az iskolaügytől a felsőoktatásig végigszervezett képzési rend egysége nem egyszerüen országok közti szakterületi átjárhatóságot biztosít, hanem európai polgárokat is nevelni hivatott: közös sémáiba a közös emberi beláthatóság elvén túl bizonyos közös emlékek is bekerülnek. A bekerülés feltételeiről zajló vitákat sokszorosan reflektált európai világunk „emlékezetpolitikának” hívja, az emlékeket pedig "emlékezethelyekhez” ${ }^{10}$ köti, teljes összhangban a hatalmi törekvések leleplezésére és értékszempontok semlegesítésére hajló tudományossággal. De vajon az egyre átfogóbb és így egyre elvontabb szemléleti kereteknek mekkora a valóságos kötőereje?

Mindezek a kérdések filozófiailag Európa úgynevezett „mibenlétéhez” vezetnek, szociológiailag pedig ahhoz a kérdéshez, most éppen milyen és hogyan is jött létre az a rend, amelyet Európának nevezhetünk. Max Weber meghatározása szerint egy társadalmi rend olyan mértékben érvényes, amilyen mértékben esély van a fennállásának elképzeléséhez való igazodásra. A puszta érdekegyezések habitusés szemléletközösségként stabilizálhatók legitim renddé. ${ }^{11}$ Igy tekintve nemcsak afelől lehetünk bizonytalanok, hogy Európa éppen most milyen mértékben létezik, hanem ennél is mélyebbre hatoló kérdés, hogy amikor - „önfelejtés” helyett - bármiképpen európai önmegőrzésünkre törekszünk, milyen életalakító rendet akarhatunk ezen a néven őrizni. Természetesen Európa és a benne zajló alakulások

\footnotetext{
' Immanuel Kant: „Válasz a kérdésre: Mi a felvilágosodás?” In uő: A vallás a puszta és határain belül és más írások. Budapest, Gondolat, 1978, 77.

${ }^{10}$ Lásd pl. Pierre Nora: Emlékezet és történelem között. Válogatott tanulmányok, Budapest, Napvilág, 2010 és Aleida Assmann: Rossz közérzet az emlékezetkultúrában. Beavatkozás. Budapest, Múlt és Jövő, 2016.

${ }^{11}$ Max Weber: Gazdaság és társadalom. A megértő szociológia alapvonalai. 1. Budapest, Közgazdasági és Jogi Könyvkiadó, 1987, 58. skk.
} 
már a külső körvonalak egyértelmű hiánya miatt sem voltak soha puszta intézményi és földrajzi tények: térbeli és időbeli határai társadalmilag rögzített és kétségbe vont természeti és történelmi pontok. Önleírásában persze az európaiság kezdettől folyamodott geográfiai kettősségekhez: Róma és Athén, Róma és Bizánc, Kelet és Nyugat, Észak és Dél, innen és túl a Limesen, az Alpokon, a Lajtán. A pólusokon és a határokon azonban keresztény és hellén, keresztény és barbár, latin és görög, katolikus és protestáns kettősségei határolódnak el egymástól és keresik egymással a közvetítést. Az összetartozónak átélt és osztatlanul érvényesnek elfogadott rend értelmében, amely azonosan orientált cselekvéseket mozgósítana, európai társadalom a sokféle szerkezeti hasonlóság ellenére nem létezik. ${ }^{12}$

Kifejlett történeti érzékünk, vagyis a változás és az alakulás iránti érzék, ez a sajátosan európai szellemi tartás a történésből az átmenetekre, alakulásokra, köztességekre tesz bennünket fogékonnyá. És bár önmaga rögzítésekor minden egység mindig is határokat von maga köré, a válság felfokozott tudata a folytonosság helyett a törésekre, az egység helyett a sokféleségre irányítja a figyelmet.

A számunkra jelentősnek látszó múltba visszanézve egy olyan kezdet tünik legelőször elénk, amely világunkat egyedülállóvá teszi. Aki ma Európát mond, olyan alakzatról beszél, amelyet újkori sajátosságai minden más kultúrvilágtól megkülönböztetnek annyiban, hogy - többek között szociológiai közmegegyezés szerint - itt született meg és innen terjedt el az, amit „modern” világnak szokás nevezni. Itt lépett színre az ember számunkra meghitten ismerős alakja, világhódító öntudatával, teremtői büszkeségével, a haladás hitével, de egyben minden szorongásával is, amelyek a külső meghasonlottságok belső megfelelői. A személyes megszólítottság bibliai üzenetét az utóbbi századok európai filozófiái az egyén páratlansága és egyszeri történése címén itt fogalmazták egzisztenciális igénnyé.

A középkori viszonylagos „egységkultúra”, amelyben a világ rendjeit az isteni teremtés vezérfogalma fogta elvileg össze, még minden belső ellentmondás és harc ellenére is egységben hordozott politikát, gazdaságot, tudományt és vallást. A birodalom a korábbi évszázadok széttagoltságából és központilag szervezetlen személyes függőségi viszonyaiból az egyház által őrzött szellemi és hivatali rendre utaltan emelkedett ki. Így zajlott együtt a világi rend moralizálódása és az egyházi rend politizálódása. Persze ebben az egységben maga a kereszténység is sokféle alakban jelent meg, a világhoz való elvi viszonyulásai szerint: a személyes bensőségességbe való visszavonulás misztikájától - az üdvösségnek egységes életvitellel

\footnotetext{
${ }^{12}$ Maurizio Bach: „Die institutionelle Dynamik Europas.” In Maurizio Bach - Barbara Hönig (Hrsg.): Europasoziologie. Handbuch für Wissenschaft und Studium. Baden-Baden, Nomos, 2018, 67. Más véleményen van, és a szerkezeti hasonlóságokra hivatkozik (család, város, jóléti állam, munka, rétegződés, fogyasztás terén) Robert Hettlage - Hans-Peter Müller (Hrsg.): Die europäische Gesellschaft. Konstanz, UVK, 2006, 44-50.
} 
elkötelezett „megváltottak” gyülekezetein át - a mindenkit születésével befogadó legtágabb és ezért erkölcsileg legmegengedőbb vallási óriásszervezetekig. ${ }^{13} \mathrm{~A}$ világon belülivé szerveződő kereszténység mindhárom egyszerre, a köztük lévő feszültségekkel együtt. Világon belüliség és világon kívüliség, más szóval intézmény és karizma ellentéte olykor kiéleződik, mint például a XII. századnak a világ felől tekintve evangéliumi radikalitású rendalapítási mozgalmaiban: a megújulást hirdetők befogadásán vagy kizárásán a törékeny egység fennmaradása múlik. Weber szavával szólva azonban a következetes vallási „testvériségetika” feloldhatatlan feszültségben van a világ saját érdekű és szemléletű szféráival. Így tekintve a középkor mégis óriási feszültségeken lett időlegesen és persze változó mértékben úrrá, ami egy evangéliuminak tartott következetesség újra és újra megerősödő igényei felől nézve kompromisszumok vállalhatatlan sorának tünhet. Az evangéliumi elvü kereszténység befogadását nem csak a kétszeres - római és bizánci - birodalmiasulás terelte eltérő tanbeli, életviteli és világrendi keretek közé. A külső rendek keretei közt újra és újra összecsap a benyomuló népcsoportok ősiségi köteléke és robusztus evilágisága a kiépült kereszténység mindinkább latin egységkultúrájával és kifinomuló lelkiségével; az önállóságra törekvő helyi uralmak részlegessége az egyházi vagy éppen birodalmi egyetemességgel. ${ }^{14} \mathrm{~A}$ Biblia latin befogadását pedig ezer évvel később, a vallási megújulás igényétől hajtva és a nemzeti önállósulás akarásától is megtámogatva, a saját nyelvű elsajátítás fogja követni, immár tömeges, de politikailag körülhatárolt közönség számára.

Az egységvilágon belüli sajátos ellentétek - a rendiség tagoltsága és a keresztény testvériesség, a kiépülő tanrendszer és az eleven érzület feszültsége - a mozgást teszik állandóvá. Ráadásul az európai középkor eltérő múltak ellentmondásait hordozta, tartotta fenn és közvetítette. Szellemi téren az Athénnal és Jeruzsálemmel szimbolizált szellemi hagyományok, vagyis a filozófiai ész racionalitása és a vallási kinyilatkoztatás hite, a polisz önkormányzó szabadsága és a szolgaság házából szabadító Istennel kötött szövetség összeegyeztetése, azaz a görögség keresztény befogadása évszázadok erőfeszítései ellenére sem sikerült végérvényesen. De a társadalmi és a szellemi zárások és nyitások túlnyomórészt egyazon világon, legalábbis annak egységfogalmán belül maradtak: a közös elvi rendből kiesni nem lehetett, a személyes mivolt gyökeres megrendülése elképzelhetetlen volt. Az egység hatalmas hordozója az európai universitas is: az egyetemeket az első alapításoktól (Bologna, XII. század) kezdve ugyanaz a tudás szervezi, amelynek horizontja a gö-

\footnotetext{
${ }^{13}$ Lásd pl. Ernst Troeltsch: Die Soziallehren der christlichen Kirchen und Gruppen. Tübingen, Mohr (Siebeck), 1. k., 197 skk.

${ }^{14}$ A kereszténység sokféle meggyökerezéséről lásd Peter Brown: Divergent Christendoms: The Emergence of a Christian Europe, 200-100o A.D. Oxford, Blackwell, 1995.
} 
rög filozófiával összekapcsolódó kereszténység, meghatározó nyilvánosságformája a kritika elvéből induló disputa.

A püspökök kettős beiktatásában még két rend tartott egyidejűleg igényt az elsőségre, de pápaság és császárság harcában fokozatosan rögzült állam és egyház intézményes elkülönülése. Bár egy végigvonuló önértelmezése szerint a kereszténység a "földi ország”-gal szemben a lehetőség szerint mindenkiben ott lakozó „isteni ország”-ra irányul, amelynek semmi köze a világbeli berendezkedéshez, ${ }^{15}$ uralom és üdvösség elve csak ekkor válik szét visszavonhatatlanul. ${ }^{16} \mathrm{~A}$ személy autonómiájának eredeztetési eltéréseit leszámítva pedig egyetértés uralkodik arról, hogy az ember legkésőbb a reformációtól kezdve mind egyéniesültebben lép a világba. Az individualitás, amit addig a nagy vallások csak a világból kivonulók számára tettek lehetővé, a protestantizmusban tömegek számára evilági formát ölt: az üdvösségét kereső mindennapi ember Isten eszközeként veti bele magát a világi munkába. ${ }^{17} \mathrm{~A}$ „regio" külső erői persze sokáig a "religio" belső támogatásához is folyamodnak: éppen ezért egyidejűleg bontakozik ki a vallási és a polgári szabadság követelése egy olyan küzdelemből, amelyet már elsősorban államok vívnak meg egymással. A felségterületi szuverenitás elve, görög és föként keresztény alapokon, egyre határozottabban az emberi szuverenitás gondolatává és akarásává személyesül. A mindenek alapjául szolgáló „szubjektum” lesz egyfelől - polgárként és egyre kevésbé alattvalóként - a világhordozás egyre jobban kidolgozott elvi alapja, másfelől az egyre inkább önállósuló világi - gazdasági, politikai - elvárások felelősnek számító megszólítottja. Az ember e bensőséges és öntudatos alakja számára aztán, a vallási tartalmaktól egyre jobban kiüresedő világi szférákban, központi értékké válik a mind evilágibb önmegvalósítás, ${ }^{18}$ amire eredendően, azaz minden közösségtől függetlenül tart igényt. Sokak diagnózisa szerint azonban egy sajátos dialektika eredményeként a személyes szabadság egyre személytelenebbé válik, ${ }^{19}$ a személyes kötöttségek helyébe formális megállapodások tömege kerül, a

\footnotetext{
${ }^{15}$ Szent Ágoston: Isten városáról IV. Budapest, Kairosz, 2009.

${ }^{16}$ A politikai teológia kérdésköréhez kultúratudományos megközelítésben lásd Jan Assmann: Uralom és üdvösség. Politikai teológia az ókori Egyiptomban, Izraelben és Európában. Budapest, Atlantisz, 2008. - A szellemi egység felbomlásaként értelmezi az újkor születését a reformációban (amely azonban a kereszténységet „halálosabban komolyan vette”) Bibó István, lásd „Az európai társadalomfejlődés értelme.” In uő: Válogatott tanulmányok, 3. kötet (1971-1979). Budapest, Magvetö, 1986, 63 skk.

${ }^{17}$ Vö. Weber klasszikus munkáját: A protestáns etika és a kapitalizmus szelleme. Budapest, L'Harmattan, 2020.

${ }^{18}$ Vö. Kurt Flasch: „Wert der Innerlichkeit” és Christoph Menke: „Innere Natur und soziale Normativität. Die Idee der Selbstverwirklichung", mindkettő in Hans Joas - Klaus Wiegandt (szerk.): Die kulturellen Werte Europas. Frankfurt a. M., Fischer, 2005.

${ }^{19}$ Georg Simmel: A pénz filozófiája. Budapest, Osiris, főként 536 skk.
} 
döntéshozás egyre formálisabb alapon rendszerezett „üzemeinek” közegében az ember alávetettsége és eldologiasodása csak fokozódik. A szociológia egyik alapító kérdése a századfordulón éppen így hangzik: hogyan lehet az egyéniség kollektív hitéből, ebből a jóformán egyetlen közös „kultuszból” egyáltalán összetartozás?2o

Ami a világ új alapzatát illeti: az elsőként Európában kibontakozó modern világ a világtörténelem első olyan berendezkedése, amely elvi alapjaiban messzemenően le akart mondani egy másik világról. Az ember elöször itt akart a maga lábán megállni: ideális önértelmezése szerint ez egy előzmények nélküli modell megvalósítási kísérlete, amelynek kapcsán máig sem eldöntött kérdés, hogy új tartalmai teológiai elemek szekularizátumai - vagy ugyanazokra a régi kérdésekre adott valóban új válaszok. ${ }^{21}$ A politikán kívül a gazdaság, a tudomány, a művészet önállósodása, azaz a vallástól és a többitől való elvi függetlenedése különálló életszférákba vonja az egyes ember napi életét. Közös új princípiumként - az esetlegesség történelemfilozófiáitól is inspirálva - a szociológia a világ „kontingenciáját” azonosítja be: bizonytalan esetlegességét egyfelől, ember általi alakíthatóságát másfelől.

A weberi szociológia egyik központi fogalma szerint a világ racionalizálása mindenekelőtt a világhoz való viszonyunk következetes elméleti vagy gyakorlati megszervezése. Ezek a folyamatok a különböző kultúrákban eltérö berendezkedésekhez vezettek, a kiinduló élmények és a szervezési szempontok jellege szerint. A bibliai veretű világban az Isten képére és hasonlatosságára teremtett ember számára a világ a tevékenység színtere: racionalizálásának szempontja az önmagunkon és a világon végzett munka aktív elve. ${ }^{22} \mathrm{~A}$ reformáció ezt terjesztette ki az élet egészének megszervezésére, miközben az eleve bünös világot felszabadította a következetes gazdaságosság, a következetes politikusság vagy éppen a következetes tudományosság előtt. Átfogóbb értelemben a világ „varázstalanodása” a mindenestül világi világ megszületését jelenti, amit végül a tudomány és a technika teljesített ki: empirikus megismerési műveleteink révén a világ immanens oksági sorok

${ }^{20}$ Lásd pl. Émile Durkheim: „Az emberi természet kettőssége és ennek társadalmi feltételei.” In Felkai Gábor - Némedi Dénes - Somlai Péter (szerk.): Szociológiai irányzatok a XX. század elejéig. Budapest, Új Mandátum, 2000, 352-362.

${ }^{21}$ A vitához Hans Blumenberg: Säkularisierung und Selbstbehauptung. Frankfurt a. M., 1974, aki az újkor eredetisége mellett érvel; vele szemben Karl Löwith: Világtörténelem és üdvtörténet. A történelemfilozófia teológiai gyökerei. Budapest, Atlantisz, 1996. A kiélezett pozíciók közti közvetítésnek tűnik Charles Taylor alább említendő helyzetértelmezése.

${ }^{22}$ Közismert, hogy technikai fejlettségben Kína a XV. századig előrébb tartott Európánál: az új európai lendület alighanem éppen a sokrétü (protestáns, reneszánsz, természettudományos) új szellemiséggel is összefüggött. Az időhöz és vele a munkához való dinamikus viszony már a középkorban bontakozik a hetek és a hétköznapok előbb kolostori, majd egyre inkább világbeli ritmusában (vö. Jacques Le Goff: Európa születése a középkorban. Budapest, Atlantisz, 2003, 43 és 259). 
mechanikus kozmoszává épül, amelyben minden - vallási vagy akár művészi nem mindennapiság egyre irracionálisabbnak minősül. ${ }^{23} \mathrm{~A}$ világnak ezt a sajátos elméleti és gyakorlati feldolgozását nevezi Max Weber a világuralás jellegzetesen nyugati és jellegzetesen újkori racionalitásának - megkülönböztetve többek között a hindu vallási következetesség világból való menekülésétől vagy a világhoz való alkalmazkodás kínai útjától. A kalkulálhatóságon és annak hitén alapuló világuralás idővel minden téren hegemoniális igényekkel lépett fel, és mihelyt lehetősége volt rá, Európából kiindulva a világ minden részére úgyszólván „gyarmatosító” módon terjedt ki. „Világ-” előtagú fogalmaink és egyben valóságaink is európai eredetűek: nemcsak a világgazdaság és a világpolitika, hanem még a „világirodalom" (Goethe) is innen kiindulva szerveződött, egyetemesnek szánt szempontok szerint. Európa története úgy hozta, hogy nagymértékben általa teremtett globális térben keresi ma a helyét. A „világ” nemcsak összhorizont, az egyetemesség foglalata, hanem leigázható tartalom is. Marx kiáltványa pontosan rögzíti a tényt, hogy a „világpiac”, Amerika felfedezésével, innen szőtte át a Földet: „A burzsoázia a világpiac kiaknázása által valamennyi ország termelését és fogyasztását kozmopolitává formálta. [...] A régi helyi és nemzeti önellátás és elzárkózottság helyébe a nemzetek sokoldalú érintkezése, egymástól való sokrétü függése lép. És ez így van nemcsak az anyagi, hanem a szellemi termelésben is." ${ }^{24}$

Ami az egyes életterületeket illeti: a gazdaság mindinkább kiszakadt az egymásra utaltság szükségletfedező társiasságából. A materiális küzdelmek ugyan szerződéses formába foglaltan zajlanak, és a hivatásbeli munka kultúrája továbbra is nélkülözhetetlen, de a tőkévé váló pénz egyre kevésbé ismer gazdaságon kívüli szempontokat. A társas világból kiágyazódó gazdaság innen indult világhódító útjára, a szükségletfedezés helyett immár tőkenyereséget akarva. A világpiaccá bővülő piac önszabályozásának akarása minden határ felülírására tör. ${ }^{25}$ Szociológiai nézőpontból a munka értéke azonban mindenekelőtt társadalmi tény: egy tevékenység nagyrabecsülése magasabb pénzértékben ölt kézzelfogható alakot. A nyugati középpontú világgazdaság a megbízható következetesség helyett ma

\footnotetext{
${ }^{23}$ Max Weber: „Bevezetés”, 66. - Bár legszűkebb értelme szerint a „varázstalanítás” az üdvösségszerzés „mágiátlanítását”, legvégül az egyházi és szentségi közvetítés kiiktatását jelenti, Weber ezt később egy több évezredes folyamatba illeszti bele, amely a bibliai próféták egyedül Jahvéhoz hűséges következetességével vette kezdetét, és az újkori tudományosság empirizmusában végződött (lásd Weber: A protestáns etika és a kapitalizmus szelleme, $81 \mathrm{skk}$.). Ami a kezdeteket illeti: a mindenkori külpolitikának az államrezonhoz igazodó királyi megfontolásai a próféta szemében nem érvénytelenek, hanem a szövetséghez képest súlytalanok.

${ }^{24}$ Karl Marx - Friedrich Engels: „A Kommunista Párt kiáltványa.” In Max és Engels válogatott müvei 1. Budapest, Kossuth, 1975, 140-141.

${ }^{25}$ A gazdaság „kiágyazódásáról” a társadalomból lásd Polányi Károly: A nagy átalakulás. Korunk gazdasági és politikai gyökerei. Budapest, Napvilág, 2004.
} 
mindinkább a kicserélhető terhelhetőséget értékeli nagyra. A hivatásbeli munka és egységes életvitel helyébe a széttöredezett feladatokhoz való alkalmazkodás elvárása lép. ${ }^{26} \mathrm{Ha}$ pedig a gazdaság új szelleme legalább részben mégis a kreativitás, az a társteremtőként felfogott ember eszméjéből is táplálkozik.

A politika önállósulásának középpontja a hatalom elve, amelyet az elfogadottságuk miatt érvényes szabályok kiterjesztése és a politikai rend bürokratikus megszervezése tesz hatékonnyá. Az erősebb hatalma persze önmagában soha nem volt tartósan elég. Az uralmi viszonyokban a politikai felszabadulás európai mozgalmai a politikai döntéshozatal sajátos rendjét kényszerítették ki, amely az „ember ember feletti uralmának minimalizálására” ${ }^{27}$ törekszik. Bár a kereszténység szociológiailag és politikailag aluldefiniáltnak mondható, amit a sokféle politikai lelkületre és szerkezetre való fogékonysága is mutat, a felebarátiság szolidaritáseszméjének meghatározó szerepe volt ennek a rendnek a megformálásában. A „polgárinak” nevezett viszonyok, vagyis az önkormányzó emberek közösségi formái ugyan a feudális rendek korlátainak középkori városi áttörésével születnek meg, de Max Weber szerint a megfoganásuk az antiokheiai keresztény asztalközösséghez kötödik, amely először bontott le minden születési korlátot..$^{28}$ Állam és egyház újkori nyugati elkülönülése mégis visszavonhatatlannak tünik, sőt Európában politika és vallás kettőssége is, noha demokratikus viszonyok között a vezetés morális szempontok szerinti legitimációra is rászorul, amit sokszor éppen a vallások biztosítanak a leghatékonyabban..$^{29}$

A tudomány rendkívüli eredményessége a felhalmozott tapasztalati tudás rendszerezésének köszönhető, egy puszta-immanens természetté és történéssé mechanizálódott világkép keretei között. Ez a szemlélet, ha következetes, végül elvi okokból elutasítja a világ „értelmére” vonatkozó kérdést. ${ }^{30} \mathrm{Az}$ intellektualizálás neutralizáló hatása éppen az értékek és a világszemlélet terén jár a legfeltűnőbb következményekkel. A többnyire Európáról elbeszélt „világtörténelem” sokáig lát-

${ }^{26}$ A vallásnak az alábbi világi szférákkal való elvi ellentétének kiéleződéséhez lásd Max Weber: „Közbevetett megfontolások.” In uő: Világvallások, 203-238. A kapitalizmus új kultúrájáról lásd Richard Sennett: The Culture of New Capitalism. New Haven, Yale University Press, 2006.

${ }^{27}$ Max Weber: Gazdaság és társadalom 1., 274. - Bibó említett írása szerint a szabadságjogok nyugati technikája (parlamentarizmus, többpártrendszer, sajtószabadság stb.), amely „az egész nyugati kultúrkör egyik legnagyobb, legmaradandóbb és legsikeresebb társadalomszervezési teljesítménye”, szellemében a keresztény erőszakmentesség programjának lecsapódása.

${ }^{28}$ Max Weber: „Hinduizmus és buddhizmus.” In uő: Világvallások, 273. sk.

${ }^{29}$ Lásd ehhez a korábban erősen valláskritikus Habermast is, pl.: Jürgen Habermas - Joseph Ratzinger: A szabadelvü állam morális alapjai. Budapest, Gondolat, 2007.

${ }^{30}$ Max Weber: „Közbevetett megfontolások”, 230. 
szik az emberi nem zsidóságban és kereszténységben "nevelődésének”, ${ }^{31}$ amely a „puszta ész” határai közé fegyelmeződve az „örök béke” felé tarthat (Kant). De miközben mindenki elismeri a modern világ teljesítményeit a gazdasági erőhalmozásban, az élet könnyítésében és a világbeli tájékozottság kiterjesztésében, ${ }^{32}$ a haladásoptimizmus mellett a kétség is erősödött: vajon a bevatkozások nem szülnek-e újabb károkat, és a tudáshalmozódás nem teszi-e egyre elérhetetlenebbé a világszemlélet konzisztenciáját. ${ }^{33} \mathrm{~A}$ világuraló öntudat éppen az asztronómia (Copernicus), a biológia (Darwin), a szociológia (Marx) és a pszichológia (Freud) nyomán rendül meg többszörösen is: az ember „nem úr a saját házában" ${ }^{34}$ Mindinkább az ész és egy sajátos tapasztalatiság színe előtt kell megállnia minden szellemi tartalomnak: a felvilágosítás a „hagyományokon” kezdte a munkáját, hogy hiteinket és meggyőződéseinket a tudományos nyelvhasználat ma már „hiedelemként” és „mítoszként” tárgyalja, az egyéni és a közös identitásokat pedig „konstrukciónak” minősítse. A tudományosság szcientizmusként világszemlélet rangjára emelkedett, a felfokozott reflexivitás és annak akár mindent aláásni is képes ereje pedig a kultúra alapműködésévé vált. ${ }^{35}$ Sajátos nyugati-európai racionalitásunk egyesek szerint az ész belső meghasonlottságai folytán vezetett el pusztító egyoldalúságokhoz. ${ }^{36}$

A vallás ilyen körülmények között a leginkább irracionális üggyé vált, legalábbis a világi szempontú racionalitások felől tekintve. A szekularizációnak nevezett mozgás az intézményes vallásosság páratlan európai visszaszorulása. Bár ez - mint az adatok mutatják - nem feltétlenül jelenti a vallás visszaszorulását, de legalábbis Európa jelentős területein a felekezetiség jelentősen meggyengült, mindenekelőtt protestáns talajon. Egészében talán ennél is lényegesebbnek tünik, hogy számos mai diagnózis szerint a vallás helye változott meg: egy választási lehetőséggé vált

${ }^{31}$ Pl. Gotthold Ephraim Lessing: „Az emberi nem nevelése.” Magyar Filozófiai Szemle, 1992, 9861012.

${ }^{32}$ Európa „csodálatos” fellendülését a despotizmus hiányával és kedvező topográfiai-éghajlati körülményekkel magyarázza a Kelettel való összehasonlításában Eric L. Jones: The European Miracle: Environments, Economics, and Geopolitics in the History of Europe and Asia. Cambridge, CUP, 20033.

${ }^{33}$ Lásd pl. Robert Münch: Die Kultur der Moderne. Frankfurt a. M., Suhrkamp, 1993.

${ }^{34}$ Lásd Sigmund Freud: „Eine Schwierigkeit der Psychoanalyse.” In Imago. Zeitschrift für Anwendung der Psychoanalyse auf die Geisteswissenschaften, 1917, 1-7.

${ }^{35}$ Ennek legfeltűnőbb szélsősége a kritika öncélúvá válása a tartalmak rovására, vagy éppen az ironikus és végül a cinikus gondolkodási stílus terjedése; lásd ehhez átfogóan Peter Sloterdijk: Kritik der zynischen Vernunft. Frankfurt a. M., Suhrkamp, 1983.

${ }^{36}$ Ennél sokkal messzebb megy Max Horkheimer és Theodor W. Adorno: A felvilágosodás dialektikája. Budapest, Atlantisz, 2020, akik szerint a XX. század történelmi katasztrófái a nyugati-európai világ elvének egyoldalú instrumentalitásából belső következetességgel fakadtak. 
a sok közül. ${ }^{37}$ A többi lehetőség egy ebbe a világba zárt transzcendenciával igyekszik megbirkózni. A vallás evidenciájának megtörése döntési jelleget ad a hitnek, a döntés pedig magánügy, még akkor is, ha meghozatala és folytonos fenntartása csoportkötődésre szorul. De éppen ezen a téren mutatkoznak a legfeltűnőbb különbségek: a modern világ elvei mintha többféle módon is megvalósulhatnának. ${ }^{38}$ Alexis de Tocqueville már a XIX. század közepén azzal a szándékkal utazta be Amerikát, hogy feltárja a különféle demokráciák sajátosságait. ${ }^{39} \mathrm{Ma}$ is érvényesnek látszó következtetését Európára alkalmazva: Amerikával ellentétben itt nemcsak az egyházat és az államot, hanem a francia forradalomtól kezdve a vallást és a politikát is elválasztották egymástól. Amerika, amely magát mindmáig szívesen írja le bibliai fogalmakkal, pl. az „ígéret földjére” bevonult kiválasztott népként, önértelmezése szerint ma is arra törekszik, hogy az egyszer megalapított jó rendhez újra és újra visszaemelkedjen, sokszor vallási megújulási mozgalmak révén. Európa, úgyszólván az ellentétes úton járva, az „eget” akarja „itt és most” a „földre” lehozni, ami új és új radikális politikai mozgalmakat gerjeszt, az evilági tökéletesség sokszor terrorisztikus igézetében. A végső beteljesüléshez egy utolsó nagy erőszak utópikus-forradalmi akarása - ez a jakobinus mozzanat - újkori európai gondolat és valóság. ${ }^{40}$ De nem csak az Európai Unió alapításának kereszténydemokrata eszméje szól a szekularitás egyértelműsége ellen: Európa vallástól való intézményes tartózkodása és intellektualista distanciája mélyén - a szekularizáció jelszava és elvárása mögött - a jelentős többség adatszerűen is nyilvánvaló vallásos kötődései rejlenek. ${ }^{41}$

${ }^{37}$ A modern világ „immanens kereteihez” és a közöttük kiépülő transzcendenciához lásd pl. Charles Taylor: A Secular Age. Cambridge, Harvard University Press, 2007. Lásd ehhez Max Horkheimer találó megfogalmazását Hamletről: „keresztény hit nélkül - keresztény lélekkel” (Zur Kritik der instrumentellen Vernunft. Frankfurt a. M., Suhrkamp, 1991).

${ }^{38}$ Vö. Shmuel N. Eisenstadt: Die Vielfalt der Moderne. Weilerswist, Velbrück, 2000.

${ }^{39}$ Alexis de Tocqueville: Az amerikai demokrácia. Budapest, Európa, 1993. „Hagyjátok, hogy az emberi elme a maga útján haladjon, és egyformán fogja berendezni a politikai társadalmat és az égi várost; arra fog törekedni, ha szabad ezt mondanom, hogy összehangolja a földet az éggel." (412.) Mintha tehát az összehangolás két eltérő irányáról lenne szó.

${ }^{40}$ Vö. Shmuel N. Eisenstadt: Die Antinomien der Moderne. Die jakobinischen Grundzüge der Moderne und des Fundamentalismus. Frankfurt a. M., Suhrkamp, 1998.

${ }^{41}$ Vö. José Casanova: Europas Angst vor der Religion. Berlin, Berlin University Press, 2009, fóként 7-30. 


\section{EURÓPA MINT ANYAGI ÉS SZELLEMI FESZÜLTSÉGTÉR}

„Európa” azonban manapság, mint ezelőtt is sokszor, inkább harci, mint leíró fogalom: az elbizonytalanodás legbiztosabb jele. Európa nélkülözi az egységesítés legősibb és legelemibb, bár soha nem kényszerítő elemeit: a történelmi sorsközösséget és a közös nyelvet. Európa fennállásának mai „esélye” nem köthető semmilyen központi helyhez. A territorialitás államalapító elvét Európára nem sikerült átvinni: az új szerveződési szint hordozói a közös szempontokon is iskolázott sajátosságokat felkínáló, az idők során királyságból nemzetállammá vált „országok”. A közvetítés hosszú múltú egységei nemcsak a lokalitásnak, hanem a szubszidiaritás keresztény elvének hordozói is. Identitásunk a legújabb kimutatások szerint is nagy arányban olyan politikai képződményekhez ragaszkodik, amelyek előzményei már ezer évvel ezelött is léteztek. ${ }^{42}$ Egy sokféleképpen tagolt társadalmi tér legkülönfélébb előfeltételei az „európaiság” eltérő alakjaihoz vezettek és vezetnek.

A pólusok mégoly kiélezett kijátszása egymással szemben valóságos eltéréseken alapszik, amit a különféle „köztességek” pozíciói közvetítenek - elvileg és valóságosan is. Az emlékezetben őrizhető „sorsközösségre” a múlt hatalmas különbségei települnek: a nyugati mór és a keleti oszmán fennhatóság nem egyformán ülepedett le Európa jelenében. A regionalitás szerinti megközelítés ${ }^{43}$ - akár materiális, akár ideális szellemben - gyökeres különbségekre lát rá: az állam és az egyén közti társadalmi tér kitöltése történelmi tapasztalástól formált lehetőségek sokféleségét mutatja. A szerves alakulások „közösségének” és a megegyezéses viszonyok „társadalmának" mindenkori aránya a politikával kapcsolatos elvárásokra is hatással van. A „közép” fogalmának szerepe többek között ezeknek a tapasztalatoknak az őrzése is. A keleti és a nyugati kereszténység példáján: az átmeneti területek életvilágában ezer év után is közvetlen bejárás van mindkét változatba. Az egységhez való lokális viszonyulások történelmi és társadalmi mélységei nagy erejü valóságok.

Eközben óriásbirodalmi elözményekig is könnyen visszahatol az európai tekintet, egészen a római birodalomig, amelynek kiterjedtsége először tette lehetővé az egységes „emberiség” tágasságában való gondolkodást. Az általános ember mivolt kötetlenségének és átjárhatóságának absztrakcióra hajló értelmiségi teoretikusai, az idegen sokféle elvi bevonási kísérletével, a sztoikusoktól kezdve szélesítik az emberi kötelékek lehetőségeit. A sokféleség közös nevezőjének keresése a kulturális hermeneutikában öltött alakot - Európában. Persze az egység akarásának indíté-

\footnotetext{
${ }^{42}$ Lásd Ferdinand Seibt: Die Begründung Europas. Ein Zwischenbericht über die letzten tausend Jahre, Frankfurt a. M., Fischer, 2002, 21.

${ }^{43}$ Lásd Szűcs Jenő társadalomszerkezeti alapú nagyszabású kísérletét: Vázlat Európa három történeti régiójáról. Budapest, Magvető, 1983.
} 
kai is sokfélék: a megbecsültség, a saját kultúra értékelő akarása eszmei érdek, az általánosságot pedig gazdasági érdekek is mozgatják, amelyek a „formális egyenlöségben" mindenekelött az egyetemes piac akadálytalanságát akarják. ${ }^{44} \mathrm{~A}$ nyitás egyetemessége ideálisan a felebarátságot vagy az emberiséget akarja, materiálisan a piac tágasságát. A gyökeres harc nem csak a külső, ${ }^{45}$ hanem a belső „idegennel” is zajlik: a határokat zárni és nyitni akarók egymást vádolják európaiatlansággal. A kívülről érkezők azonban nem általános emberek és nem puszta munkaerők, ahogy a magát európainak tartó ember sem az.

A társas szerkezetek befogadóképessége tehát nemcsak a „számok súlyától”, hanem értékek és meggyőződések erejétől is függ. Európa közös szellemi gyökerei a felvilágosodáson, a reformáción és a reneszánszon keresztül az ókori görög és a bibliai világba nyúlnak vissza, ez az a talaj, amelyen a mai európai ember is áll. De hát „mennyi föld kell az embernek?” - teszi fel a kérdést Tolsztoj, és evangéliumi ihletésü válasza: amekkorába eltemethető. A protestáns exisztencialista filozófus Kierkegaard szerint éppen ideje, hogy a fennálló kereszténységbe (Christenhed) újra bevezessük a krisztushitet (Christendom); ahogy a katolikus teológus Johann Baptist Metz intelme szerint a kereszténységnek nem szabad a világba belepolgáriasodnia. A kultúra szociológiája közben empirikus tapasztalatokra hivatkozik: a kulturális alakzatoknak terekre van szükségük. A világban berendezkedő szellemi-lelki erők a fennmaradás érdekében elkerülhetetlenül megindulnak az intézményesülés útján, ami könnyen vezet az eredeti karizmatikusság elernyedéséhez: a gyökerek feletti esztétikai kellemességérzés feledteti az eredeti nem-mindennapiságot. De például a szenvedésre való érzékenység eszkatologikus horizontját nem feltétlenül homályosítják el a tágas agorák, a gondolkodás roppant csarnokai vagy az ég felé emelkedő templomok. A szociológia nyelvén szólva: a nyitások mindig zárásokat is előfeltételeznek.

Ókortudósok gyakran írták le azt a folyamatot, amelynek során ókori magaskultúrákban a korábban jogi formulák erkölcsi szellemmel telítődtek. Az újkori Európa, úgyszólván az ellenkező irányú pályán haladva, a rend rendkívüli megtartóképességü vívmányaként egyre formalizáltabb szellemben szervezte meg a jogot. A kettősségek kezelése évszázadok óta a Rómától teremtett jog folyamatosan újragondolt eszközeivel bizonyul a leghatékonyabbnak. Az európai rend, a pusztító vallásháborúk tapasztalataiból is tanulva: jogilag rendezett sokféleség. Ám a jogi formalizálás soha nem tud teljesen kiürülni: fogantatásának kulturális nyomait

${ }^{44}$ Lásd pl. Max Weber: Gazdaság és társadalom 2/3. Budapest, Közgazdasági és Jogi Könyvkiadó, $1996,80 \mathrm{sk}$.

${ }^{45}$ Le Goff hivatkozása szerint első alkalommal 1453-ban, Konstantinápoly eleste után II. Pius pápa szerepeltette címben az „Európa” szót, óva intve az oszmán fenyegetéstől (Európa születése a középkorban, 242). 
mindig magán viseli. A belső békét és egymás elfogadását szem előtt tartó jogrendünk a személy értékfogalmán nyugszik. Szociológiai belátás szerint azonban az intézményes rendek megtartó önereje véges. Az intézményeket odaadás és elkötelezettség tartja meg a legerősebben. A törvényeknek engedelmeskedő jogközösség nem nélkülözheti a fennhatósága körébe tartozó értékközösségeket. ${ }^{46} \mathrm{~A}$ jogban mindig meglévő kockázat: mindenek formai eljogiasítása, közös ügyek mellett elkötelezett hatalmi döntések helyett.

Mint láttuk persze, megrendült hagyományos elkötelezettségeink között és azokon belül is gyökeres feszültségek és ellentmondások vannak. Ellentétbe kerülhet a hit igénye az ész követeléseivel, a teljesség és kizárólagosság a sokféleséggel, az univerzalitás a pluralitással, a világteremtő elméletiség az ugyanilyen szempontú gyakorlatisággal, az ésszerűség az elevenséggel, és még az individualitáson belül is az általános emberi a páratlanul egyszerivel. A „varázstalanodás” roppant folyamataival pedig mindig együtt járnak „varázsos” ellenmozgások: a földhözkötött mindennapiság vagy éppen a művészi és vallási nem-mindennapiság felé. Minden ellentmondás ellenére ez a mi saját feszültségterünk, amelyben görög és keresztény külső és belső alakzatok, szellemi és valóságos tereink, javaink és alkatunk megőrzött habitusa tette lehetővé a reneszánszokat és reformációkat. ${ }^{47}$ Európa sajátos szellemi és anyagi termékenysége ellentmondásos összetevőinek folyamatos újraértelmezéséből is fakadt. ${ }^{48} \mathrm{Az}$ önmagára adott új és új válaszok feszítőerejét a sokféle múlt találkozása adja, amelyeket elvi tételek nem tudnak végérvényessé egynemüsíteni. A „közjó” így konkrét és többféle „köz” sajátos „javait” hordozza, amelyek egységesítése a befogadható változatok közös akarássá hangolását jelenti. A tapasztalások és emlékezések sajátosságai a legközösebb „jó” értésébe is beáradnak: a szabadság ezért szorul regulatív eszmeként is folyamatos értelmezésre. A szabadság fogalma egyénibb és közösségibb változatokat is megenged. Elveink kritikai újragondolása is európai princípium.

Ami elveinket illeti: ha a szabadság abszolútnak tekinti magát, elkerülhetetlennek tűnik a háborúja más eszményekkel, ahogy az igazságosság eltérő szempontjai is összeegyeztethetetlen világnézetekben gyökereznek. ${ }^{49} \mathrm{~A}$ filozófiai gondolkodás

${ }^{46}$ Robert Spaemann: „Európa - értékközösség vagy jogrend?” 2000, 2002.

${ }^{47}$ Ernst Cassirer: „Die »Tragödie der Kultur«." In Ralf Konersmann (Hrsg.): Kulturphilosophie. Leipzig, Reclam, 1998, 107-140.

${ }^{48}$ Ujjabban ehhez Karl-Siegbert Rehberg: „Europabilder. Imaginationen und Realisierungen eines Kontinents.” In Maurizio Bach - Barbara Hönig (szerk.): Europasoziologie, 15-31. Lásd még Jean-Marc Ferry: „Az európai közösség »filozófiája«." In uő - Paul Thibaud: Vita Európáról. Budapest, L’Harmattan, 2006, főként 155 skk.

${ }^{49}$ Az igazságosság eltérő értelmezési lehetőségeihez Michael Walzer: Spheres of Justice: A Defense of Pluralism and Equality. New York, Basic Books, 1983. 
története a központi fogalmaink vitája: minden sokféleségben is európai, hogy éppen ezekről a kérdésekről gondolkodunk.

Egy szociológiai tanulságokat is beszámító kultúratan a meglévő keretek megtartására úgy tekinthet, mint megörökölt tartalmak és lehetőségek újraértelmező őrzésére. A nagy materiális és szellemi mozgalmak egyetemes tágasságra törnek: univerzalitás és partikularitás feszültségét újra és újra az ellentétig kiélezik. Az univerzalitások persze nem ugyanazt akarják: minden általánosító átgondolás a sajátot tágítja globálissá. A legegyetemesebbnek akart tudások is világélményekhez és világlátomásokhoz kötődnek. A szociológiai veretű kérdés ezért úgy hangzik: mai állapotában mennyi és milyen globalitást bír el az európai ember, ${ }^{50}$ más szóval itt és most mennyi és milyen partikularitások nélkülözhetetlenek?

Európa sajátos jegye, hogy a lokalitás elvi hordozóinak ügye és a nagyobb egységek teremtésének és őrzésének küldetése összekapcsolódik. Az emlékezetközösség lehetősége és feladata - az általánosan befogadott hagyományelemeken túl - az egymás elleni harcok szenvedéstörténeteiről való közös megemlékezésen és a közöshöz való sajátos hozzájárulások emlékezetén alapszik. A kereszténység népek felettisége, akárcsak a filozófia hétköznapi ész felettisége a világpolgárság gondolatáig hatol, felülírva minden hagyományos megkülönböztetést. Csakhogy a „nemzeti” összetartozás érzése, minden sokrétűsége ellenére, erőteljes presztízst nyer mindazokból a kultúrjavakból, amelyek az odatartozóknak, azaz az anyagi és szellemi folytonosság kiemelkedő alakjainak tulajdoníthatók. Az európaiság kezdettől - a birodalom és a törzsek, a kereszténység és a mágikus szellemhitek találkozása óta - változatokba konkretizáltan létezik. Ennek a kettősségnek - a nemzeti és európai mivoltnak - a hordozói azok, akik jelentős mértékben érintkeznek ezekkel a kultúrjavakkal. De hogy is lehetne másként, ha minden kultúra, így az európai is, közös szellemi viszonyulás és konkrét életforma? ${ }^{51}$ Európa sajátja, hogy a vélt vagy valós begyökerezettségek ősiséginek tartott tényezői is, sajátos hozzájárulásukra támaszkodva, befolyást keresnek: a csoportos identitások - amilyen a népek, nemzetek identitása - konkrét tér- és időbeli kiterjedést is igényelnek.

A nyelvközösségek egymásra maradéktalanul nem lefordíthatók: a középkori misztikából is táplálkozó, teljes világmetafizikát hordozó Geist akár aszketikus komolysága és szellemdús elkötelezettsége nem ugyanaz, mint a szent és profán lélekben fogant esprit akár hús-vér elevensége és kifinomult lelkülete. Európa gaz-

\footnotetext{
${ }^{50}$ Vö. Rüdiger Safranski: Mennyi globalizációt bír el az ember? Budapest, Európa, 2004.

${ }^{51}$ Utóbbihoz a maga történeti gazdagságában Wolfgang Reinhard: Lebensformen Europas. Eine historische Kulturanthropologie. München, C. H. Beck, 2006. Maga ez a történetírás is sokszor már csak mint a „jövő eredetének” számbavétele (Odo Marquard), az apokaliptikus szellemben „kirekesztettek hozzánk tartozásának” rögzítése (Joachim Ritter) nyilvánvalóan ehhez az életformához tartozik.
} 
dagsága mindez egyszerre: a közös megszólítottságra adott sokféle válasz közössége. A felelős személyiség ősdialógusa Paul Ricœur szerint mindenesetre így hangzik: „Ábrahám, hol vagy?” - „Itt vagyok.”

\section{4. ÖSSZEGZÉS}

Az összefonódó emlékezetekben gyökerező európai programközösség a mindenkori másikkal is számol. Az egységesítő szellemi tartalmak elviségére szorítkozva: a klasszikus görögség elötti archaikus rétegekbe való visszahatolás újra és újra elemi őserők „,igazi” teremtését (Nietzsche) és önmagunkhoz való viszonyunk „hitelességét” (Foucault) keresi. A zsidóság horizontja „Egyiptom”, amelynek köréből a gyökeres szabadulás és a szellem melletti döntés - minden európai szabadságtörténet modelljeként - a mi számunkra is megtörtént, de az eredetet keresve ismétlődően kirajzolódik egy „egyiptomi Mózes” ellenemlékezete is. ${ }^{53} \mathrm{~A}$ világistenné egyetemesedő Jahve halványuló vonásai egy távoli hegyen lakó „haragvó” Istent mutatnak. A kereszténység ebben a világban - népekben, felekezetekben - rendezkedett be, de „nem ebből a világból” választott orientációs pontokat. Az utóbbi idők felszabadító programjai a mitikus ösztönök és tudatalatti archetípusok (Freud, Jung), a termelési szükségletek (Marx) „valóságosabbnak” vélt mélybirodalma felé tapogatóznak, a felvilágosult ész pedig újra és újra számot vet az érzések, a tapasztalás és a hit elevenségével.

Európa mindig is szellemi és anyagi kultúrák találkozásának, befogadásának, elsajátításának és küzdelmének is helye volt. A bármilyen önmegőrzés folytonosságához ragaszkodó kultúrák sajátos tapasztalata a kettősségek termékenysége mindaddig, amíg azok saját elvi kereteik közé vonhatók. Bár az újkori Európa kritikai elve a folytonos változás bevonásában volt szellemileg és intézményileg is hatékony, legújabban mintha mindinkább a saját szellemi gyökereit kérdőjelezné meg. A Teremtés könyvének alapító történetén illusztrálva: Isten és világ, ég és föld, nappal és éjszaka, Isten és ember, ember és természet alapvető kettősei egymás után vesztik el határaikat. A kritika elve persze roppant bevonóerőt fejthet ki, amíg a másikból is töltekezve nem önmagát számolja fel, új alapításra képtelenül.

A sokfélébe vesző történeti érzék és a totális egységigény között „Európa” a múltjainkon nyugvó vállalásokként ölthet alakot, mindannak komoly vitákban

${ }^{52}$ Vö. Paul Ricœur: Soi-même comme un autre. Paris, Seuil, 1990 és uő: Wege der Anerkennung. Erkennen, Wiedererkennen, Anerkannt-sein. Frankfurt a. M., Suhrkamp, 2006.

${ }^{53}$ Lásd ehhez Jan Assmann: Exodus. Die Revolution der alten Welt. München, C. H. Beck, 2015 és uő: Mózes, az egyiptomi. Egy emléknyom megfejtése. Budapest, Osiris, 2003, valamint Sigmund Freud: Mózes az ember és az egyistenhit. Budapest, Európa, 1987. 
alakuló foglalataként, amiben magunkra ismerünk. ${ }^{54}$ Sokféle eredetvonal rekonstruálható a jelenig, amelyek megújuló tanulmányozása - sajátosan hermeneutikai kultúraként ${ }^{55}$ - a külső és belső tagoltsághoz illő európai sajátosság. Szellemi téren a szó és a gondolat meghatározó erején alapszik minden „kontinentális”-nak mondott világértelmezés, de még a nyelviség analitikus tagolásán át vezető út is. ${ }^{56}$ Ami az embernek önmagához, másokhoz és a világhoz való viszonyát illeti, a belső ember önfeltáró szabadsága ${ }^{57}$ és teremtő alkotása az elismerés kölcsönösségében, az egymásra utaltság jól rendezett kötelékei között: ez a bibliai és görög eredetű, hosszú távon kiformálódott újkori európai emberalak és az általa hordozott rend mindenesetre nem egyeztethető össze bármilyen világprogrammal.

\section{BIBLIOGRÁFIA}

Assmann, Aleida: Rossz közérzet az emlékezetkultúrában. Beavatkozás. Ford. Huszár Ágnes. Budapest, Múlt és Jövő, 2016.

Assmann, Jan: Exodus. Die Revolution der alten Welt. München, C. H. Beck, 2015.

Assmann, Jan: Mózes, az egyiptomi. Egy emléknyom megfejtése. Ford. Gulyás András. Budapest, Osiris, 2003.

Assmann, Jan: Uralom és üdvösség. Politikai teológia az ókori Egyiptomban, Izraelben és Európában. Ford. Hidas Zoltán. Budapest, Atlantisz, 2008.

Bach, Maurizio: „Die institutionelle Dynamik Europas.” In Maurizio Bach - Barbara Hönig (Hrsg.): Europasoziologie. Handbuch für Wissenschaft und Studium. Baden-Baden, Nomos, 2018.

Bibó István: „Az európai társadalomfejlődés értelme.” In uő: Válogatott tanulmányok, 3. kötet (19711979). Budapest, Magvető, 1986.

Blumenberg, Hans: Säkularisierung und Selbstbehauptung. Frankfurt a. M., 1974.

Brown, Peter: Divergent Christendoms: The Emergence of a Christian Europe, 200-100o A.D. Oxford, Blackwell, 1995.

Casanova, José: Europas Angst vor der Religion. Berlin, Berlin University Press, 2009.

Durkheim, Émile: „Az emberi természet kettőssége és ennek társadalmi feltételei.” In Felkai Gábor Némedi Dénes - Somlai Péter (szerk.): Szociológiai irányzatok a XX. század elejéig. Budapest, Új Mandátum, 2000, 352-362.

${ }^{54}$ Lehetséges emlékezésközösségként a jelenlegi Európa éppen az a háromezer éves távlat, amelyet Goethe a tájékozódás feltételének tart: „Aki három ezredévről / nem képes, hogy számot adna, / ki nem talál a sötétből, / vakon élhet napról napra.” (J. W. Goethe: Nyugat-keleti díván. Budapest, Magyar Könyvklub, 2001, 96, Kálnoky László ford.)

${ }^{55}$ Vö. Wolfgang Reinhard: „Die hermeneutische Lebensform des Abendlandes.” In uő (Hrsg.): Sakrale Texte. Hermeneutik und Lebenspraxis in den Schriftkulturen. München, C. H. Beck, 2009, 68-119.

${ }^{56} \mathrm{Az}$ egyetlen amerikai születésű, bár európai inspirációktól is áthatott filozófia alighanem a pragmatizmus.

${ }^{57}$ Ahogy Amerikának - Tocqueville szerint - az egyenlőség szélsőségeivel kell megküzdenie, úgy Európa számára a szabadság elve okoz újra és újra gondot. 
Eisenstadt, Shmuel N.: Die Antinomien der Moderne. Die jakobinischen Grundzüge der Moderne und des Fundamentalismus. Frankfurt a. M., Suhrkamp, 1998.

Eisenstadt, Shmuel N.: Die Vielfalt der Moderne. Weilerswist, Velbrück, 2000.

Cassirer, Ernst: „Die »Tragödie der Kultur «. In Ralf Konersmann (Hrsg.): Kulturphilosophie. Leipzig, Reclam, 1998, 107-140.

Ferry, Jean-Marc: „Az európai közösség »filozófiája«.” In uő - Paul Thibaud: Vita Európáról. Budapest, L'Harmattan, 2006.

Flasch, Kurt: „Wert der Innerlichkeit”. In Hans Joas - Klaus Wiegandt (Hrsg.): Die kulturellen Werte Europas, Frankfurt a. M., Fischer, 2005

Freud, Sigmund: „Eine Schwierigkeit der Psychoanalyse.” In Imago. Zeitschrift für Anwendung der Psychoanalyse auf die Geisteswissenschaften, 1917, 1-7.

Freud, Sigmund: Mózes az ember és az egyistenhit. Ford. F. Ozorai Gizella. Budapest, Európa, 1987.

Goethe, J. W.: Nyugat-keleti diván. Ford. Kálnoky László. Budapest, Magyar Könyvklub, 2001.

Gyurgyák János: Európa alkonya? Utak és tévutak az európai történelemben és politikában. Budapest, Osiris, 2018

Habermas, Jürgen - Ratzinger, Joseph: A szabadelvü állam morális alapjai. Ford. Horváth Károly. Budapest, Gondolat, 2007.

Hegel, Georg Wilhelm Friedrich: Elöadások a világtörténet filozófiájáról. Ford. Szemere Samu. Budapest, Akadémiai, 1966.

Hegel, Georg Wilhelm Friedrich: Grundlinien der Philosophie des Rechts. Werke 7. Frankfurt a. M., Suhrkamp, 1970.

Hettlage, Robert - Müller, Hans-Peter (Hrsg.): Die europäische Gesellschaft. Konstanz, UVK, 2006.

Hidas Zoltán: Törékeny értelemvilágaink. A világalakitás rendje és szabadsága. Budapest, Gondolat, 2018.

Horkheimer, Max - Adorno, Theodor W.: A felvilágosodás dialektikája. Ford. Glavina Zsuzsa, Bayer József, Geréby György, Vörös T. Károly. Budapest, Atlantisz, 2020.

Jones, Eric L.: The European Miracle: Environments, Economics, and Geopolitics in the History of Europe and Asia. Cambridge, CUP, 2003.

Kant, Immanuel: „Válasz a kérdésre: Mi a felvilágosodás?” In uő: A vallás a puszta és határain belül és más írások. Ford. Vidrányi Katalin. Budapest, Gondolat, 1978, 77-104.

Le Goff, Jacques: Európa születése a középkorban. Ford. Sujtó László. Budapest, Atlantisz, 2003.

Lessing, Gotthold Ephraim: „Az emberi nem nevelése.” Magyar Filozófiai Szemle, 1992, 986-1012.

Löwith, Karl: Világtörténelem és üdvtörténet. A történelemfilozófia teológiai gyökerei. Ford. Miklós Tamás, Boros Gábor. Budapest, Atlantisz, 1996.

Mannheim Károly: Tudásszociológiai tanulmányok. Ford. Bendl Júlia, Karádi Éva, Kisbali László, Bognár Virág, Hofstaedter Herbert. Budapest, Osiris, 2000.

Marx, Karl - Engels, Friedrich: „A Kommunista Párt kiáltványa.” In Max és Engels válogatott müvei 1. Budapest, Kossuth, 1975.

Menke, Christoph: „Innere Natur und soziale Normativität. Die Idee der Selbstverwirklichung.” In Hans Joas - Klaus Wiegandt (Hrsg.): Die kulturellen Werte Europas. Frankfurt a. M., Fischer, 2005.

Münch, Robert: Die Kultur der Moderne. Frankfurt a. M., Suhrkamp, 1993.

Németh István (szerk.): Európa-tervek. 1300-1945. Budapest, Eötvös, 2001.

Nora, Pierre: Emlékezet és történelem között. Válogatott tanulmányok. Ford. Németh Orsolya, Lajtai L. László, Haas Lídia, Tóth Réka, K. Horváth Zsolt. Budapest, Napvilág, 2010.

Polányi Károly: A nagy átalakulás. Korunk gazdasági és politikai gyökerei. Budapest, Napvilág, 2004. Rehberg, Karl-Siegbert: „Europabilder. Imaginationen und Realisierungen eines Kontinents.” In Bach, Maurizio - Barbara Hönig (Hrsg.): Europasoziologie, 15-31. 
Reinhard, Wolfgang: Lebensformen Europas. Eine historische Kulturanthropologie. München, C. H. Beck, 2006.

Reinhard, Wolfgang: „Die hermeneutische Lebensform des Abendlandes.” In uő (Hrsg.): Sakrale Texte. Hermeneutik und Lebenspraxis in den Schriftkulturen. München, C. H. Beck, 2009, 68-119.

Ricœur, Paul: Soi-même comme un autre. Paris, Seuil, 1990.

Ricœur, Paul: Wege der Anerkennung. Erkennen, Wiedererkennen, Anerkannt-sein. Frankfurt a. M., Suhrkamp, 2006.

Safranski, Rüdiger: Mennyi globalizációt bír el az ember? Budapest, Európa, 2004.

Schluchter, Wolfgang: „Interessen, Ideen, Institutionen: Schlüsselbegriffe einer an Max Weber orientierter Soziologie." In uő: Die Entzauberung der Welt. Sechs Studien zu Max Weber. Tübingen, Mohr Siebeck, 2009, 18-39.

Seibt, Ferdinand: Die Begründung Europas. Ein Zwischenbericht über die letzten tausend Jahre. Frankfurt a. M., Fischer, 2002.

Sennett, Richard: The Culture of New Capitalism. New Haven, Yale University Press, 2006.

Simmel, Georg: A pénz filozófiája. Ford. Berényi Gábor. Budapest, Osiris, 2004.

Sloterdijk, Peter: Kritik der zynischen Vernunft. Frankfurt a. M., Suhrkamp, 1983.

Spaemann, Robert: „Európa - értékközösség vagy jogrend?” 2000, 2002.

Szent Ágoston: Isten városáról IV. Ford. Heidl György, Dér Katalin. Budapest, Kairosz, 2009.

Szűcs Jenő: Vázlat Európa három történeti régiójáról. Budapest, Magvető, 1983.

Taylor, Charles: A Secular Age. Cambridge, Harvard University Press, 2007.

Tocqueville, Alexis de: Az amerikai demokrácia. Budapest, Európa, 1993.

Troeltsch, Ernst: Die Soziallehren der christlichen Kirchen und Gruppen. Tübingen, Mohr (Siebeck), 1912.

Wallerstein, Immanuel: Bevezetés a világrendszer-elméletbe. Ford. Koltai Mihály Bence. Budapest, L'Harmattan, 2010.

Walzer, Michael: Spheres of Justice: A Defense of Pluralism and Equality. New York, Basic Books, 1983.

Weber, Max: Gazdaság és társadalom. A megértő szociológia alapvonalai. 1. Ford. Erdélyi Ágnes. Budapest, Közgazdasági és Jogi Könyvkiadó, 1987.

Weber, Max: Gazdaság és társadalom 2/3. Budapest, Közgazdasági és Jogi Könyvkiadó, 1996.

Weber, Max: „A társadalomtudományos és társadalompolitikai megismerés »objektivitása«" In uő: Tanulmányok. Ford. Józsa Péter, Erdélyi Ágnes, Lannert Judit, László Géza, Wessely Anna. Budapest, Osiris, 1998, 7-69.

Weber, Max: „Bevezetés.” In uő: Világvallások gazdasági etikája. Vallásszociológiai tanulmányok. Válogatás. Endreffy Zoltán, Tatár György, Somlai Péter, Mesés Péter, Hidas Zoltán, Ábrahám Zoltán. Budapest, Gondolat, 2007.

Weber, Max: A protestáns etika és a kapitalizmus szelleme. Budapest, L’Harmattan, 2020. 